\title{
A morphometric study of ductus arteriosus and its implications for implant of occlusive devices
}

\author{
LEAO, S. C. ${ }^{*}$, QUEIROZ, A. A. F. ${ }^{2}$, SOUTO, M. J. S. ${ }^{2}$, ALMEIDA, R. O. ${ }^{2}$, \\ MACIEL, D. C. ${ }^{2}$ and RODRIGUES, T. M. A. ${ }^{2}$
}

\author{
${ }^{1}$ Department of Pathology, Paulista School of Medicine, Universidade Federal de São Paulo - UNIFESP, \\ Rua Borges Lagoa, 1332 , CEP 04038-032, São Paulo, SP, Brazil \\ ${ }^{2}$ Group of Molecular Anatomy, Department of Morphology, Universidade Federal de Sergipe - UFS, \\ Av. Marechal Rondon, s/n , CEP 49000-100, São Cristovão, SE, Brazil \\ *E-mail: sydneyleao@hotmail.com
}

\begin{abstract}
Introduction: The ductus arteriosus is a blood vessel which connects the pulmonary artery to the aortic arch. This binding occurs opposite to the origin of left subclavian artery. The pulmonary trunk is an artery that carries deoxygenated blood from the right ventricle to the lungs. Objective: Make a morphometric study on the aorta and pulmonary artery beyond ductus arteriosus in a population of individuals between 9-26 weeks of gestation, constituting a database that can assist interventional surgeons for closure of the ductus arteriosus. Methods: It was measured weight, vertex-rump, vertex-heel lengths, head and chest circumferences, and anatomical measures concerning the ductus arteriosus of 44 human fetuses with gestational ages ranging from nine to 26 weeks. Inferential analysis was performed by Student's t test and Pearson's correlation (R) and the significance level was 0.05 . Results: It was observed that, among the 44 fetuses, $22.72 \%$ had gestational age between nine and 14 weeks; $61.36 \%$ had between 15-20 weeks; and 15.90\% had between 21-26 weeks of gestation. Regards morphological parameters, there are significant statistical differences for some parameters, such as diameter of the aorta+ pulmonary trunk $(\mathrm{p}<0.0001)$; diameter of the aorta $(\mathrm{p}: 0.01)$; diameter of the pulmonary trunk (p: 0.007); diameter of the ductus base at the aorta $(\mathrm{p}<0.0001)$. Conclusion: It is known that the earlier the correction of patent ductus arteriosus, increased patient survival. Therefore, it is necessary to develop instruments that allow the approach in extremely preterm infants with improved modes of treatment.
\end{abstract}

Keywords: congenital heart defects, ductus arteriosus, fetuses, occlusive devices, prematurity.

\section{Introduction}

The aorta is the largest and the most important artery of the human body. It begins from the left ventricle and ends at the level of the fourth lumbar vertebra, where it divides into the common iliac arteries. The aorta is usually divided into five segments: ascending, arch of aorta, descending, thoracic and abdominal aorta (GOSS, 1977).

The pulmonary trunk (PT) is an artery that carries deoxygenated blood from the right ventricle to the lungs. It arises from the pulmonary annulus of the basis of right ventricle and below of the aortic arch it divides into right and left pulmonary arteries. In the fetus, at the level of the bifurcation the pulmonary artery is connected to the aortic arch by the ductus arteriosus (STRANDING, 2005).

The ductus arteriosus (DA) is a blood vessel which connects the pulmonary artery to the aortic arch. This binding occurs opposite and distal to the origin of the left subclavian artery. After birth, the ductus should occlude up spontaneously due to contraction of its muscular wall, as a result of the difference of pressure between the right and left chambers of the heart (HERRMAN, BOSE, LEWIS et al., 2009).

These structures have a common embryological origin. They arise from the forth and sixth pharyngeal archs. Aorta and pulmonary trunk are originated from an embryonic dilatation, called truncus asteriosus. During fetal life, when blood pressure is similar in pulmonary trunk and aorta, the structure of these vessels is similar. After birth, the pulmonary vascular resistance decreases, whereas blood flow increases (STRANDING, 2005). These changes lead to increased thickness of the aortic wall in relation to the pulmonary artery. Moreover, the DA must occlude spontaneously due to their muscle contraction wall, as a result of the pressure difference between the right and left chambers of the heart (HERRMAN, BOSE, LEWIS et al., 2009).

When this does not happen, there is the persistence of the ductus arteriosus (PDA). The patent ductus arteriosus (PDA) is one of the most common congenital heart diseases and corresponds to approximately $5-10 \%$ of all cardiac malformations (HADDAD, LIMA FILHO, FIGUEIREDO et al., 2005; ARNONI, PEÑA, FONTES et al., 2007; HOFFMANN, 2009; MOORE, BROOK and HEYMANN, 2008). The treatment of this disease is indicated in the first year of life when there is heart failure or later, when there are hemodynamic consequences of the defect (MOORE, BROOK and HEYMANN, 2008; RICHARDS, JOHNSON, FOX et al., 2009).

In this sense, the ductus arteriosus closure can be approached in two ways: clinical or surgical. The clinical treatment involves administration of prostaglandin inhibitors such as ibuprofen or indomethacin (FANOS, PUSCEDDU, DESSI et al., 2011). Surgical management can be done by the intervention median thoracotomy type or minimally invasive, with occlusion of the 
channel through artifacts implantation in the catheterization laboratory, the most effective approach for this disease (ARNONI, PEÑA, FONTES et al., 2007).

The main objective of this article is to make a morphometric study on the major blood vessels (aorta and pulmonary artery) beyond ductus arteriosus in a population of individuals between 9-26 weeks of gestation. This article have the importance of constituting a morphometric database that can assist groups of interventional surgeons to find alternatives for filling and subsequent closure of the ductus arteriosus in populations as desafiant from the eyes of modern science such as newborn between 25 and 30 weeks of gestation.

\section{Materials and Methods}

\subsection{Study population}

44 fetuses with gestational age between nine and 26 weeks, preserved by freezing in natura, were analyzed. These fetuses were obtained from the Social Service of Nossa Senhora de Lourdes Maternity, located in Aracaju city - SE, through an agreement between the State Secretariat of Health and the Federal University of Sergipe, according to Brazilian Legislation on donation of cadavers, Law number 8501/92, and were under the custody of the Museum of Human Anatomy Profesor Dr. Oswaldo da Cruz Leite. The project was approved by the Committee of Ethics in Research involving Human Beings, which belongs to the University Hospital of the Federal University of Sergipe, under the CAAE number 0039.0.107.000-09.

For analyses purposes, the sample was divided into three groups, according to gestational age. The first one was composed of fetuses with gestational age between nine and 14 weeks; in the second one were those with age between 15 and 20 weeks; and the third group corresponded to fetuses between 21 and 26 weeks of development.

\subsection{Dissection technique}

The fetuses were thawed under running water and had their measures of weight, vertex-buttock length (VB), vertex-calcaneus length (VC), cephalic perimeter (CP), and thoracic perimeter (TP) registered. Except weight, which was measured in grams $(\mathrm{g})$, all the other variables were measured in millimeters $(\mathrm{mm})$.

It was also carried out the necropsy of each fetus, beginning with an inverted "Y"-like incision, starting from the manubrium sterni, in the median plane, until the diaphragm. After incision and release of internal structures, it was possible to withdraw each thoracic block, which underwent immersion in formaldehyde solution diluted to $4 \%$ and posterior freezing in freezer.

In the next step, the thoracic blocks were thawed in a water bath for about one hour. After thawing and removal of the thymus and pericardium, the dissection, which was carried out with tweezer of Watson, began. With the help of a mesoscopy and the digital caliper rule "Coolant Proof ABSOLUTE" Series 500 - DIN 862 - IP 66, Mitutoyo - Suzano - SP, Brazil, the following measurements were made: diameter of the aorta + pulmonary trunk (D); aortic diameter (E); diameter of the pulmonary trunk $(\mathrm{F})$-being these three variables measured at the outlet of the heart - ; diameter of the ductus base at the aorta $(\mathrm{G})$; diameter of the ductus base at the pulmonary trunk $(\mathrm{H})$; ductus length $(\mathrm{I})$; and distance from the ductus to the heart $(\mathrm{J})$. All these data were measured in millimeters $(\mathrm{mm})$, and the letters chosen to represent these variables are arbitrary.

\subsection{Statistical analysis}

For the statistical study of the collected data, it was used a microcomputer configured with the operating system Windows 7 Professional Copyright $^{\oplus}$ 2009, Microsoft Corporation Readmond, WA 98052, USA. The program Microsoft Office Excel $^{\odot} 2007$ was used to calculate the Pearson correlation between gestational age and the other variables, average and standard deviation, and the application GraphPad Prism $6^{\odot}$ 2012, GraphPad Software, Inc. - La Jolla, CA 92037, USA was used to calculate the statistical significance $(\mathrm{p})$ of the sample. The level of significance adopted was $5 \%(\mathrm{p}<0.05)$.

\section{Results}

It was observed that, among the 44 fetuses that composed the sample, $10(22,72 \%)$ had gestational age between nine and 14 weeks; $27(61,36 \%)$ had between 15 and 20 weeks; and seven $(15,90 \%)$, between 21 and 26 weeks of gestation.

In the first group, composed of fetuses with gestational age between nine and 14 weeks, the average age was $12.9 \pm 1.60$ weeks and the average weight was $155.30 \pm 56.40 \mathrm{~g}$. In the group formed by fetuses with gestational age between 15 and 20 weeks, it was observed that the averages were $17.58 \pm 1.55$ weeks for age and $351.11 \pm 105.10 \mathrm{~g}$ for weight. The third group, composed of fetuses with 21 to 26 weeks of gestation, had an average age of $23.33 \pm 2.30$ weeks and $777.14 \pm 187.81 \mathrm{~g}$ for average weight.

As represented in Table 1 , the average vertex-buttock length (VB) found for different groups was $151.7 \pm 33.21 \mathrm{~mm}$ (9-14 weeks); $179.11 \pm 36.85$ ( 15 -20 weeks) and $253 \pm 32.33 \mathrm{~mm}$ (21-26 weeks) $(\mathrm{p}<0.0001)$. It was also found $212.60 \pm 43.90 \mathrm{~mm}$ (9-14 weeks); $230.29 \pm 71.34$ (15-20 weeks) and 362.57 \pm 61.66 (21-26 weeks) for average vertex-calcaneus length (VC) $(\mathrm{p}<0.0001)$. The average cephalic perimeters $(\mathrm{CP})$ for different groups are $128.8 \pm 22.48 \mathrm{~mm}$ (9-14 weeks); $184 \pm 47.99 \mathrm{~mm}$ (15-20 weeks) and 218.85 \pm 30.53 (21-26 weeks) $(\mathrm{p}<0.0001)$. The average thoracic perimeters (TP) are $107.6 \pm 21.30$ (9-14 weeks); 158.22 \pm 37.87 (15-20 weeks) and 175.28 \pm 18.69 (21-26 weeks) $(<0.0001)$.

Table 1. Mean values of biometric parameters correlated with gestational age - There are significant stastistical differences for all biometric parameters.

\begin{tabular}{ccccrc}
\hline Subjects & Age $($ Weeks $)$ & VB $(\mathrm{mm})$ & \multicolumn{1}{c}{ VC $(\mathbf{m m})$} & \multicolumn{1}{c}{ CP $(\mathrm{mm})$} & TP $(\mathrm{mm})$ \\
\hline 10 & 09 a 14 & $151.7 \pm 33.21$ & $212.6 \pm 43.89$ & $128.8 \pm 22.48$ & $107.6 \pm 21.30$ \\
27 & 15 a 20 & $179.11 \pm 36.85$ & $230.29 \pm 71.34$ & $184 \pm 47.99$ & $158.22 \pm 37.87$ \\
7 & 21 a 26 & $253 \pm 32.33$ & $362.57 \pm 61.66$ & $218.85 \pm 30.53$ & $175.28 \pm 18.69$ \\
& p & $<0.0001$ & $<0.0001$ & $<0.0001$ & $<0.0001$ \\
\hline
\end{tabular}

VB: Vertex-buttock length; VC: Vertex-calcaneus length; CP: cephalic perimeter; TP: Thoracic Perimeter. 
The average ductus arteriosus dimensions found in this age group were: $1.68 \pm 0.67 \mathrm{~mm}$, for the length; $0.93 \pm 0.56 \mathrm{~mm}$, for the diameter at the aorta; and $1.05 \pm 0.5 \mathrm{~mm}$, for the diameter at the pulmonary trunk.

The analysis of Table 2 shows that diameter of the aorta + pulmonary trunk (D), aortic diameter (E), diameter of the pulmonary trunk $(\mathrm{F})$ - being these three variables measured at the outlet of the heart - and the diameter of the ductus base at the aorta $(\mathrm{G})$ were significant data for this group. We found the following average values for the different groups: diameter of the aorta + pulmonary trunk (D) $-4.84 \pm 1.61$ (9-14 weeks); 6.74 $\pm 1.81 \mathrm{~mm}$ (15-20 weeks); $8.09 \pm 1.67$ (21-26 weeks) (p: 0.001); diameter of the aorta $(\mathrm{E})=2.58 \pm 1.04$ (9-14 weeks); $3.74 \pm 1.07 \mathrm{~mm}$ (15-20 weeks) and 3.67 \pm 0.85 (21-26 weeks) (p: 0.014); diameter of the pulmonary trunk $(\mathrm{F})=2.32 \pm 0.93(9-14$ weeks $) ; 3.62 \pm 1.21$ (15-20 weeks); $3.86 \pm 1.06$ (21-26 weeks) (p: 0.007); diameter of the ductus base at the aorta $(\mathrm{F})=0.93 \pm 0.55(9-14$ weeks $) ; 1.49 \pm 0.71$ (15-20 weeks); $2.30 \pm 0.45$ (21-26 weeks) (<0.0001). For the other groups, there are not statistical significant differences between them.

The linear functions for all significant parameters are (D)- diameter of the aorta + pulmonary trunk: $\mathrm{y}=0,3247 \mathrm{x}+0,8666(\mathbf{R}: \mathbf{0 , 5 8 9 9} ; \mathbf{p}<\mathbf{0 , 0 0 0 1}) ;(\mathrm{E})$ - diameter of aorta: $y=0,1258 x+1,2788(\mathbf{R}: \mathbf{0 , 4 0 2 6} ; \mathbf{p : 0 , 0 0 6}) ;(\mathrm{F})$ diameter of the pulmonary trunk: 0,162lx+0,5403 (R: 0,4687; p: 0,001);
(G) Diameter of the ductus base at the aorta: 0,1011x $-0,2658$ (R:0.4816, p<0,0001) (Figures 1-4).

\section{Discussion}

In our article, the ductus arteriosus and all other significant parameters showed linear growth in terms of length and diameter through fetal life which is in agreement with some authors (URSELL, BYRNE, FEARS et al., 1991; ACHIRON, ZIMAND, HEGESH et al., 2000; SZPINDA, 2005). For them, the volume of the majority of arteries increased approximately according to a quadratic function. However, other authors (HOFSTETTER, ENGELHARDT, PRUNTE et al., 1987; LEHMANN, 1994) did not find correlation between age and arterial diameter correlating them to body weight and other study (SZPINDA, SZWESTA and SZPINDA, 2007) showed a decrease on the relative diameter of the ductus arteriosus from the second trimester to third trimester of gestacional age. Also, in our study, all the parameters of fetal biometry (VB, VC, CP, TP and weight) showed a significant increase with age. We believe that both age and weight, normally growing fetuses, can be used as reliable parameter to estimate the diameter and length of the major vessels of the body.

The correlation coefficients between absolute values of significant parameters and fetal age are all moderate, being parameter D (diameter of the aorta + pulmonary trunk), the strongest of them (R: 0.5899). A previous study

Table 2. Mean values of some parameters correlated with gestational age - There are significant stastistical differences for some parameters.

\begin{tabular}{ccccccccc}
\hline Subjects & $\begin{array}{c}\text { Age } \\
\text { (Weeks) }\end{array}$ & $\mathrm{D}(\mathrm{mm})$ & $\mathrm{E}(\mathrm{mm})$ & $\mathrm{F}(\mathrm{mm})$ & $\mathrm{G}(\mathrm{mm})$ & $\mathrm{H}(\mathrm{mm})$ & $\mathrm{I}(\mathrm{mm})$ & $\mathrm{J}(\mathrm{mm})$ \\
\hline 10 & 09 a 14 & $4.84 \pm 1.61$ & $2.58 \pm 1.04$ & $2.32 \pm 0.93$ & $0.93 \pm 0.55$ & $1.05 \pm 0.50$ & $1.68 \pm 0.67$ & $2.67 \pm 1.36$ \\
27 & 15 a 20 & $6.74 \pm 1.80$ & $3.74 \pm 1.07$ & $3.62 \pm 1.21$ & $1.49 \pm 0.71$ & $1.49 \pm 0.78$ & $2.49 \pm 1.15$ & $2.66 \pm 1.68$ \\
7 & 21 a 26 & $8.09 \pm 1.67$ & $3.67 \pm 0.85$ & $3.86 \pm 1.06$ & $2.30 \pm 0.45$ & $1.64 \pm 0.64$ & $2.64 \pm 0.50$ & $1.53 \pm 0.97$ \\
& p & $\mathbf{0 . 0 0 1}$ & $\mathbf{0 . 0 1 4}$ & $\mathbf{0 . 0 0 7}$ & $<\mathbf{0 . 0 0 0 1}$ & 0.172 & 0.068 & 0.211 \\
\hline
\end{tabular}

$\mathrm{D}=$ diameter of the aorta + pulmonary trunk; $\mathrm{E}=$ diameter of the aorta; $\mathrm{F}=$ diameter of the pulmonary trunk; G: diameter of the ductus base at the aorta; H: diameter of the ductus base at the pulmonary trunk; I: ductus length; J: channel distance to the heart.

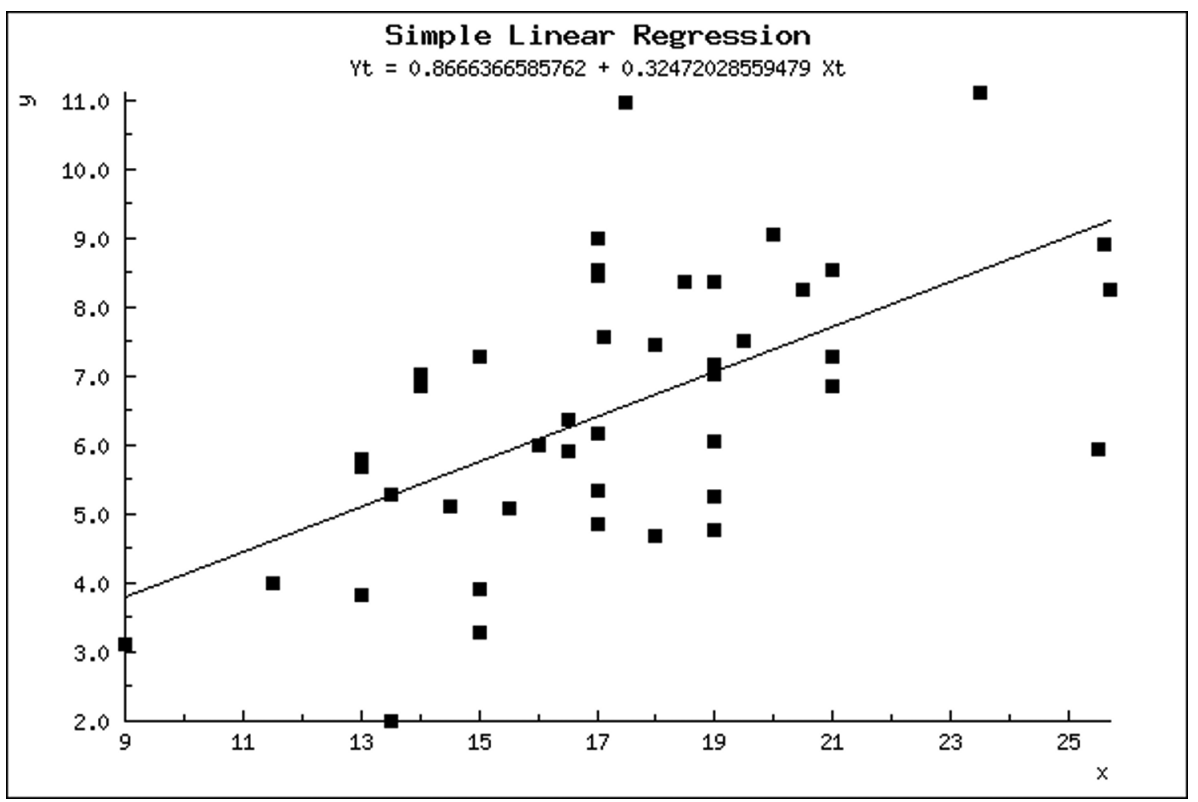

Figure 1. Regression line between gestacional age $(\mathrm{x})$ and parameter D (diameter of aorta+ pulmonary trunk) (y). 


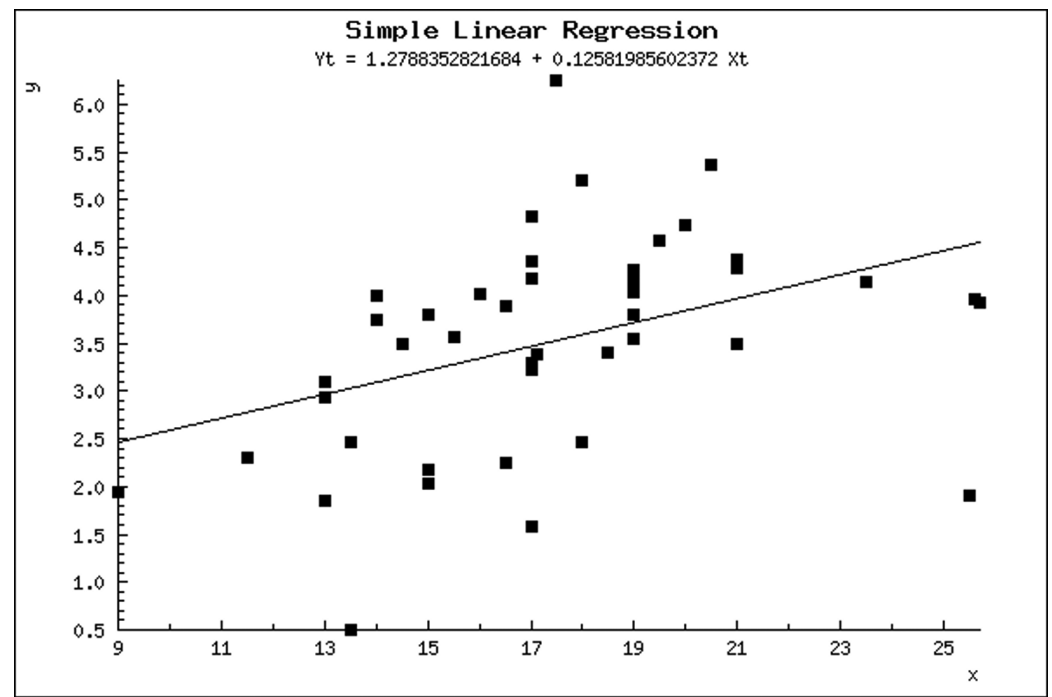

Figure 2. Regression line between gestacional age (x) and parameter $\mathrm{E}$ (diameter of aorta) (y).

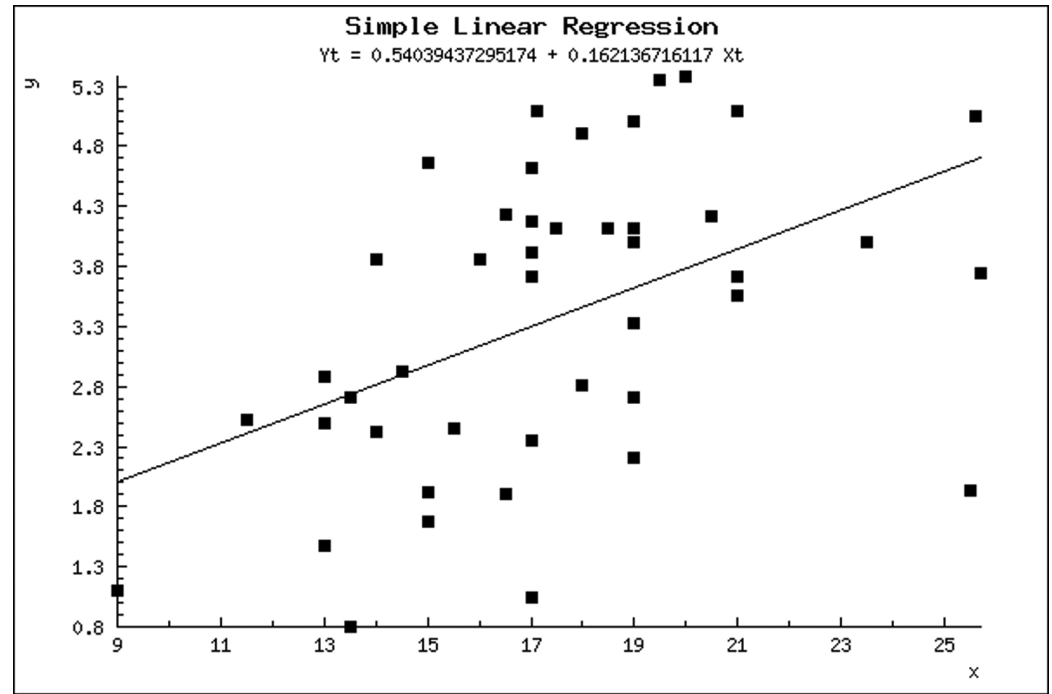

Figure 3. Regression line between gestacional age (x) and parameter F (diameter of pulmonary trunk) (y).

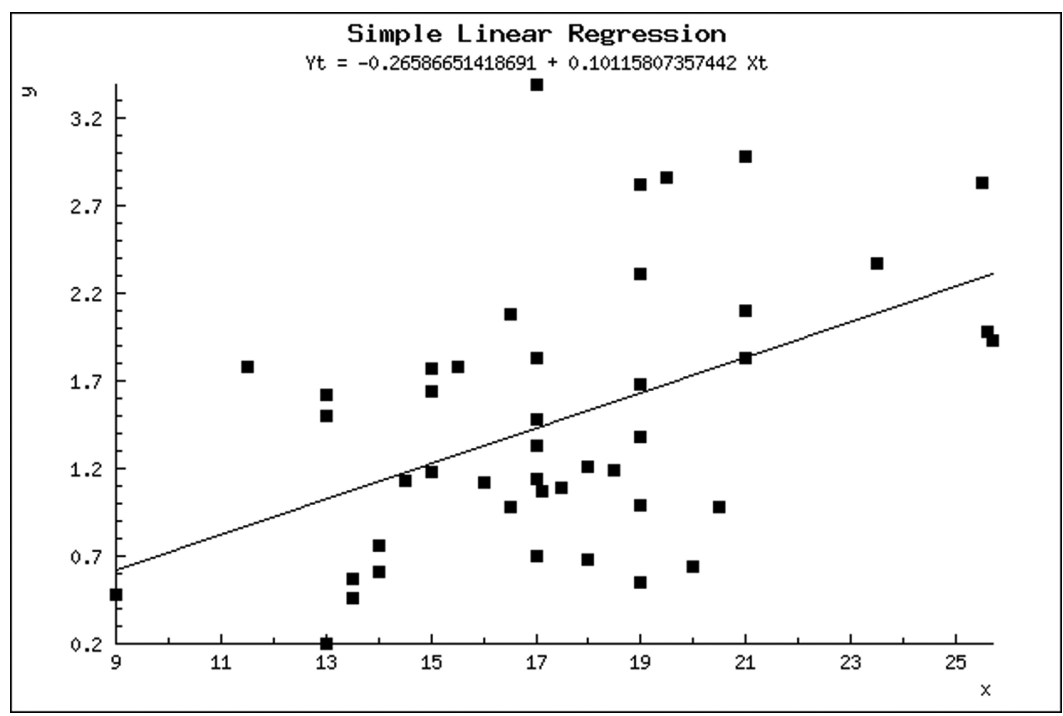

Figure 4. Regression line between gestacional age (x) and parameter G (Diameter of the ductus base at the aorta) (y). 
(SZPINDA, SZWESTA and SZPINDA, 2007), showed very high correlation between ductus parameters $(0.98$ for length and 0.90 for diameter) and fetal age. Despite the alterations in blood flow after closing of the ductus, a previous study (VAN MEURS-VAN WOEZIK and KREDIET, 1982) found that the internal diameters of the aorta and aortic isthmus of the cases with an open duct did not differ significantly from those with a closed duct (SZPINDA, BRAZIS, ELMINOWSKAWENDA et al., 2006).

It is known that there is no consensus on the best approach to patent ductus arteriosus after birth. Either separately or in combination, constitutes a major challenge for groups working with these patients. In this sense, we have witnessed in recent years, the progressive acquisition of technology, which enables more and more, the management of extreme newborns, including those born with a thousand grams, or even below this level (PEDRA, ESTEVES, BRAGA et al., 2008; FAELLA and HIJAZI, 2000).

Since the 90s, percutaneous occlusion with Gianturco springs has occurred, especially in cases of channels larger than $3.0 \mathrm{~mm}$ (ARNONI, PEÑA, FONTES et al., 2007; OWADA, TEITEL and MOORE, 1997) present in children weighing more than five kilograms (PEDRA, ESTEVES, BRAGA et al., 2008; HIJAZI and GEGGEL, 1994). However, this approach has not proven safe and effective in the case of extremely premature newborns weighing less than one kilogram. (SANT'ANNA, COSTA, RIBEIRO et al., 2012; FAELLA and HIJAZI, 2000). Thus, the technological challenge that is needed is to develop tools that can be used in these preterm.

\section{Conclusion}

So the challenge was launched for interventional groups that militate in this endeavor, which must seek, with the basic science data that can support the approach of these neonates. That way, you can take treatment option, if not in the neonatal period up to 28 days of birth, at least until the first year of life, minimizing the deleterious effects of this state of overflow by patent ductus arteriosus.

\section{References}

ACHIRON, R., ZIMAND, S., HEGESH, J., LIPITZ, S., ZALEL, Y. and ROTSTEIN, Z. Fetal aortic arch measurements between 14 and 38 weeks' gestation: in utero ultrasonographic study. Ultrasound in Obstetrics \& Gynecology, 2000, vol. 15, n. 3, p. 226-230. http:// dx.doi.org/10.1046/j.1469-0705.2000.00068.x. PMid:10846779.

ARNONI, D.G., PEÑA, J.J.S., FONTES, V.F., BRAGA, S.L.N., ESTEVES, C.A., FERREIRA, W.P., PEDRA, S.R.F.F., SANTANA, M.V.T., SANTIN, J.C., SILVA, J.M.F., O'CONNOR, R. and PEDRA, CAC. Oclusão percutânea do canal arterial $>3 \mathrm{~mm}$ com auxílio do biótomo. Revista Brasileira de Cardiologia Invasiva, 2007, vol. 15, n. 2 , p. 134-140. http://dx.doi.org/10.1590/S2179-83972007000200008.

FAELLA, H.J. and HIJAZI, ZM. Closure of the patent ductus arteriosus with the amplatzer PDA device: immediate results of the international clinical trial. Catheterization and Cardiovascular Interventions, 2000, vol. 51, n. 1, p. 50-54. http://dx.doi.org/10.1002/1522726X(200009)51:1<50::AID-CCDll>3.0.CO;2-6. PMid:10973018.

FANOS, V., PUSCEDDU, M., DESSI, A. and MARCIALIS, MA. Should we definitively abandon prophylaxis for patent ductus arteriosus in preterm new-borns? Clinics, 2011, vol. 66, n. 12, p. 21412149. http://dx.doi.org/10.1590/S1807-59322011001200022. PMid:22189742.
GOSS, CM. Gray's anatomy of the human body. 29th ed. Philadelphia: Lea and Febiger, 1977. 448 p.

HADDAD, J., LIMA FILHO, M.O., FIGUEIREDO, G.L., NAZZETTA, H.E. and OSTERNE, ECV. Oclusão percutânea da persistência do canal arterial. Revista Brasileira de Cardiologia Invasiva, 2005, vol. 13, n. 3, p. 206-218.

HERRMAN, K., BOSE, C., LEWIS, K. and LAUGHON, M. Spontaneous closure of the patent ductus arteriosus in very low birth weight infants following discharge from the neonatal unit. Archives of Disease in Childhood. Fetal and Neonatal Edition, 2009, vol. 94, n. 1, p. F48-F50. http://dx.doi.org/10.1136/adc.2007.129270. PMid:18450808.

HIJAZI, Z.M. and GEGGEL, RL. Results of anterograde transcatheter closure of patent ductus arteriosus using single or multiple Gianturco coils. The American Journal of Cardiology, 1994, vol. 74, n. 9, p. 925-929. http://dx.doi.org/10.1016/0002-9149(94)90588-6. PMid:7977123.

HOFFMANN, JIE. Patent ductus arteriosus. In HOFFMANN, JIE. (Ed.). The natural and unnatural history of congenital heart disease. Philadelphia: Wiley Blackwell, 2009. p. 79-92.

HOFSTETTER, R., ENGELHARDT, W., PRUNTE, K., ROTHER, A. and VON BERNUTH, G. Sector echocardiographic determination of the diameter of the large arteries of the heart in children. Zeitschrift fur Kardiologie, 1987, vol. 76, n. 1, p. 38-43. PMid:3564616.

LEHMANN, ED. Biophysical properties of the aorta. Lancet, 1994, vol. 354 p. 1763-1772.

MOORE, P., BROOK, M.M. and HEYMANN, MA. Patent ductus arteriosus and aortopulmonary window. In ALLEN, HD., DRISCOLL, DJ., SHADDY, RE. and FELTES, TF. (Eds.). Heart disease in infants, children, and adolescents. New York: Lippincott Williams \& Wilkins, 2008. p. 683-701.

OWADA, C.Y., TEITEL, D.F. and MOORE, P. Evaluation of Gianturco coils for closure of large ( $>$ or $=3.5 \mathrm{~mm}$ ) patent ductus arteriosus. Journal of the American College of Cardiology, 1997, vol. 30, n. 7, p. 1856-1862. http://dx.doi.org/10.1016/S0735-1097(97)00382-3. PMid:9385919.

PEDRA, CAC., ESTEVES, CA., BRAGA, SLN., PEDRA, SRFF., PONTES JUNIOR, SC., SILVA, MAP., ALMEIDA, GMAL., SANTANA, MVT. and FONTES, VF. Oclusão percutânea do pequeno canal arterial com molas de gianturco: impacto da otimização da seleção das molas e dos pacientes e da não-tolerância ao fluxo residual significativo imediato nos resultados. Revista Brasileira de Cardiologia Invasiva, 2008, vol. 16, n. 1, p. 86-90.

RICHARDS, J., JOHNSON, A., FOX, G. and CAMPBELL, M. A second course of ibuprofen is effective in the closure of a clinically significant PDA in ELBW infants. Pediatrics, 2009, vol. 124, n. 2, p. e287-e293. http://dx.doi.org/10.1542/peds.2008-2232. PMid:19651568.

SANT'ANNA, LOC., COSTA, RN., RIBEIRO, MS., NASCIMENTO, WT., PEREIRA, FL., NEVES, J., ARRIETA, SR, FONTES, VF. and PEDRA, CAC. Oclusão percutânea do canal arterial com a prótese Amplatzer $^{\circledR}$ vascular plug II: experiência inicial em três centros de referência. Revista Brasileira de Cardiologia Invasiva, 2012, vol. 20, n. 2, p. 191-198.

STRANDING, S. Gray's anatomy: the anatomical basis of clinical practice. 39th ed. New York: Churchill Livingstone, 2005. 1600 p.

SZPINDA, M. Angiographic study of the tibioperoneal trunks in patients with aorto-iliac occlusive disease. Annals of Anatomy, 2005, vol. 187, n. 4, p. 405-410. http://dx.doi.org/10.1016/j. aanat.2005.02.012. PMid:16163854. 
SZPINDA, M., BRAZIS, P., ELMINOWSKA-WENDA, G. and WISNIEWSKI, M. Morphometric study of the aortic and great pulmonary arterial pathways in human fetuses. Annals of Anatomy, 2006, vol. 188, n. 1, p. 25-31. http://dx.doi.org/10.1016/j. aanat.2005.08.014. PMid:16447909.

SZPINDA, M., SZWESTA, A. and SZPINDA, E. Morphometric study of the ductus arteriosus during human development. Annals of Anatomy, 2007, vol. 189, n. 1, p. 47-52. http://dx.doi.org/10.1016/j. aanat.2006.06.008. PMid:17319608.

URSELL, P.C., BYRNE, J.M., FEARS, T.R., STROBINO, B.A. and GERSONY, WM. Growth of the great vessels in the normal human fetus and in the fetus with cardiac defects. Circulation, 1991, vol. 84, n. 5, p. 2028-2033. http://dx.doi.org/10.1161/01.CIR.84.5.2028. PMid:1934377.

VAN MEURS-VAN WOEZIK, H. and KREDIET, P. Measurements of the descending aorta in infants and children: comparison with other aortic dimensions. Journal of Anatomy, 1982, vol. 135, n. 2, p. 273-279. PMid:7174502.

Received January 15, 2015 Accepted November 18, 2015 